\title{
Hypercalcemia Caused By Concomitant Graves Disease and Primary Hyperparathyroidism
}

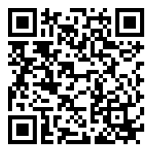

\author{
Xinjiang Cai, Pegah Yousefzadeh and Xiangbing Wang* \\ Department of Medicine, Robert Wood Johnson Medical School, USA
}

Submission: November 11, 2017; Published: February 05, 2018

*Corresponding author: Xiangbing Wang, Division of Endocrinology, Metabolism \& Nutrition, Department of Medicine,Rutgers-Robert Wood Johnson University Hospital, MEB384B,1 RWJ Place, P.O. Box 19,New Brunswick, NJ 08903, USA, Tel: 732-235-7751; Fax: 732-235-7069; Email: wangx9@rwjms.rutgers.edu

\section{Summary}

Here, we present the clinical course, laboratory results and management and review pertinent literature for a rare case of concomitant Graves' disease and primary hyperparathyroidism associated with hypercalcemia. A 71 years old African American woman presented with generalized fatigue, polyuria, polydipsia, and poor appetite for a few weeks. On admission, laboratory values showed serum calcium level of $12.3 \mathrm{mg} / \mathrm{dL}$, albumin of $3.6 \mathrm{~g} / \mathrm{dL}$, iPTH of $37 \mathrm{pg} / \mathrm{mL}$, PTH related peptide of $0.2 \mathrm{pmol} / \mathrm{L}$, $25(\mathrm{OH})$ vitamin D of $65 \mathrm{ng} / \mathrm{mL}$, TSH of $0.01 \mathrm{uIU} / \mathrm{mL}$, and free T4 of 7.1ng/dL. I-123 uptake and scan of the thyroid showed $44 \%$ homogeneous uptake at 24 hours. The patient was initially diagnosed with hypercalcemia related to hyperthyroidism. She received intravenous hydration and was treated with $25.9 \mathrm{mCi}$ of I-131 2 months later. The serum calcium remained $10.4-10.7 \mathrm{mg} /$ $\mathrm{dL}$ (range, $8.6-10.4 \mathrm{mg} / \mathrm{dL}$ ) after freeT4 normalized to $1.58 \mathrm{ng} / \mathrm{dL}$. Repeat labs revealed serum ionized calcium of $5.9 \mathrm{mg} / \mathrm{dL}$, iPTH of $65 \mathrm{pg} / \mathrm{mL}$ and 24 - hour urinary calcium of $166.4 \mathrm{mg}$, which is consistent with primary hyperparathyroidism. Hypercalcemia in Graves' hyperthyroidism should warrant a thorough investigation for concomitant primary hyperparathyroidism.

\section{Background}

Thyroid and parathyroid disease may coexist [1-3]. Cases of synchronous thyroid pathology have been observed in patients presenting with primary hyperparathyroidism (PHPT), suggesting the importance of preoperative evaluation of thyroid gland $[1,2]$. We have previously reported the coexistence of thyroiditis and thyroid nodules with parathyroid disorders $[4,5]$ and the development of PHPT after radioactive iodine-131 (RAI) treatment for Graves' hyperthyroidism [6,7]. Wahl et al. [8] found that the prevalence of PHPT was about 1\% among 5450 patients referred for thyroid surgery, which can create a challenge in the clinical decision making and management of these patients. It is optimal to deal with both problems in one operative procedure if surgery is required [1]. However, there are fewer case reports or studies emphasizing the importance of searching for PHPT in Graves' disease patients with concomitant hypercalcemia. Here we report a unique case of hypercalcemia caused by hyperthyroidism and PHPT.

\section{Case Presentation}

A 71 years old African American woman with a past medical history of hypertension, colon cancer and anxiety disorder was admitted to the hospital with generalized fatigue, polyuria, polydipsia, and poor appetite for a few weeks. On examination, she was anxious. Her blood pressure was $118 / 68 \mathrm{~mm} \mathrm{Hg}$, heart rate 108 , respiratory rate 14 , and she was afebrile. Extra-ocular muscles were intact with mild proptosis. The thyroid was normal in size, non-tender, and without bruits. Cardiovascular examination was notable for a $2 / 6$ systolic ejection murmur. The pulmonary, abdominal, and neurologic examinations were unremarkable. There was trace bilateral lower extremity edema.

\section{Investigation}

Laboratory values showed a serum calcium of $12.3 \mathrm{mg} /$ $\mathrm{dL}$ (range, 8.6-10.4), albumin of $3.6 \mathrm{~g} / \mathrm{dL}$ (range, 3.5-4.8), intact parathyroid hormone $(\mathrm{iPTH})$ of $37 \mathrm{pg} / \mathrm{mL}$ (range, 15$65)$, parathyroid hormone (PTH) related peptide of $0.2 \mathrm{pmol} / \mathrm{L}$ (normal, <2), $250 \mathrm{H}$ vitamin D of $65 \mathrm{ng} / \mathrm{mL}$ (range, 30-74), thyroid stimulating hormone (TSH) of $0.01 \mathrm{uIU} / \mathrm{mL}$ (range, 0.45 4.50), and free thyroxine (T4) of 7.1ng/dL (range, 0.82-1.77). I-123 uptake and scan of the thyroid showed $20 \%$ and $44 \%$ homogeneous uptake at 4 and 24 hours, respectively. Thyroid ultrasound showed a multi-nodular goiter with a dominant $1.8 \mathrm{~cm}$ complex hyperechoic nodule in the right lower lobe with mild vascularity and no microcalcification. The patient was diagnosed with hypercalcemia related to hyperthyroidism.

\section{Treatment}

She received intravenous hydration and was started on methimazole and propranolol. Prior to discharge, the serum calcium improved to $11.2 \mathrm{mg} / \mathrm{dL}$ (range, 8.6-10.4) and free $\mathrm{T} 4$ improved to $5.53 \mathrm{ng} / \mathrm{dL}$ (range, 0.82-1.77). Two months later, she was treated with $25.9 \mathrm{mCi}$ of I-131. 


\section{Outcome and Follow-Up}

Even though the free T4 returned to normal at $1.58 \mathrm{ng} / \mathrm{dL}$ (range, 0.82-1.77), the serum calcium remained $10.4-10.7 \mathrm{mg} / \mathrm{dL}$ (range, 8.6-10.4). Repeat labs revealed serum ionized calcium of $5.9 \mathrm{mg} / \mathrm{dL}$ (range, 4.5 - 5.6), intact PTH of $65 \mathrm{pg} / \mathrm{mL}$ (range, 15$65), 24$ - hour urinary calcium of $166.4 \mathrm{mg}$ (range, 100-300), and $25(\mathrm{OH})$ vitamin D of $46.4 \mathrm{ng} / \mathrm{mL}$ (range, $30-74$ ); those lab values were consistent with the diagnosis of PHPT. She was advised to stay well hydrated and monitor calcium levels with regular follow up as she did not meet the guideline for the parathyroidectomy.

\section{Discussion}

The association between PHPT and thyroid disease, either benign or malignant, has been documented in the literature. Indeed, up to $65 \%$ of patients with PHPT have associated thyroid abnormality [9]. However, hypercalcemia caused by the coexistence of hyperthyroidism and PHPT, especially in the absence of previous neck irradiation, is extremely rare [10-12]. Only few cases have been reported in the English literature, and most reports originated from Asia [9]. Hypercalcemia occurs in up to $8 \%$ of patients with hyperthyroidism. The increased calcium release into the circulation is due to the increased bone resorption. Hypercalcemia suppresses the secretion of PTH, leading to hypercalciuria, which protects against hypercalcemia but leads to negative calcium balance in hyperthyroid patients [13]. Persistence of hypercalcemia after the normalization of TSH, however, is suggestive of other etiologies for hypercalcemia and work-up of PHPT is warranted. In our case, the diagnosis of Graves' disease is suggested by low TSH, high free T4, and high diffuse I-123 uptake. The diagnosis of primary hyperparathyroidism is suggested by high calcium and non-suppressed iPTH level.

In a retrospective study involving 96 patients admitted for elective hyperthyroidism surgery, 13 were diagnosed with hyperthyroidism associated with PHPT but none showed clinical manifestations of hypercalcemia [14]. Among these 13 patients, 11 had a parathyroid adenoma, and two had parathyroid hyperplasia. In another study conducted by Wagner et al. [15] 13387 patients who were referred to an outpatient department for thyroid diseases were screened for the presence of PHPT. The prevalence of PHPT was significantly higher in patients with thyroid diseases when compared with patients without thyroid disease $(26 / 9017=0.29 \%$ vs. $4 / 4370=0.09 \%)$. Among patients with thyroid disease, the occurrence of PHPT was significantly higher in patients with euthyroid goiter, with the highest prevalence in patients with thyroid carcinoma. These findings suggest that serum calcium should be measured for patients referred to thyroid disease screening.

Arem et al. [10] reported the coexistence of Graves' disease and primary hyperparathyroidism in two patients undergoing medical management of hyperthyroidism. Serum free calcium level was initially markedly augmented -1.61 and $1.71 \mathrm{mM}$ (normal, 1.12 to 1.28). However, the increase in immunoreactive
PTH values was only marginal. Both cases were successfully managed by parathyroidectomy and subtotal thyroidectomy for hyperparathyroidism and thyrotoxicosis, respectively. Thyroid hormone could potentiate the osteoclastic effects of PTH and exacerbate hypercalcemia, which then led to a relative suppression of PTH secretion by the abnormal parathyroid tissue [10]. In our case, hypercalcemia was initially associated with a normal iPTH level of $37 \mathrm{pg} / \mathrm{mL}$ (range, 15-65), possibly caused by the effect of hypercalcemia potentiated by hyperthyroidism to suppress iPTH in concomitant PHPT. In addition, the initial normal iPTH level suggested PHPT since iPTH level would likely be suppressed if hypercalcemia was caused by hyperthyroidism alone. After the patient received methimazole and radioiodine treatment and became euthyroid, serum calcium values remained high and iPTH increased to abnormal values suggestive of hyperparathyroidism.

\section{Conclusion}

In conclusion, hypercalcemia in patients with hyperthyroidism and normal iPTH levels should warrant a thorough investigation for possible concomitant PHPT. In this case reported here, preferred treatment should be combined thyroidectomy and parathyroidectomy.

\section{Funding}

This research did not receive any specific grant from any funding agency in the public, commercial or not-for-profit sector.

\section{Declaration of Interest}

The authors declare that there is no conflict of interest that could be perceived as prejudicing the impartiality of the research reported.

\section{Patient Consent}

A written informed consent was obtained from the patient.

\section{Author Contributions and Acknowledgements}

Dr. Wang is the patient's main physician and is the corresponding author.

\section{References}

1. Beus KS, Stack BC (2004) Synchronous thyroid pathology in patients presenting with primary hyperparathyroidism. Am J Otolaryngol 25(5): 308-312.

2. Morita SY, Somervell H, Umbricht CB, Dackiw AP, Zeiger MA (2008) Evaluation for concomitant thyroid nodules and primary hyperparathyroidism in patients undergoing parathyroidectomy or thyroidectomy. Surgery 144(6): 862-866.

3. Goldfarb M, O Neal P, Shih JL, Hartzband P, Connolly J, et al. (2009) Synchronous parathyroid carcinoma, parathyroid adenoma, and papillary thyroid carcinoma in a patient with severe and long-standing hyperparathyroidism. Endocr Pract 15(5): 463-468.

4. Huang C, Wang X (2012) Subacute thyroiditis manifesting as a thyroid mass, vocal cord paralysis, and hypercalcemia. Endocr Pract 18(2): e17-20.

5. Farooki A, Wang X (2006) Transient subclinical hyperparathyroidism in a patient with hashimoto's thyroiditis. Endocr Pract 12(3): 338-340. 
6. Wang X, Renedo MF (2004) Graves' disease occurring after hyperparathyroidism and subacute thyroiditis. Endocr Pract 10(6): 509-511.

7. Koh E, Kim D, Wang X (2011) Case series of hyperparathyroidism associated 131 RAI for Grave's disease. Endocr Rev 32: P1-P243.

8. Wahl RA, Hentschel F, Vorlander C, Schabram J (2000) Primary hyperparathyroidism--early diagnosis in patients referred for thyroid surgery. Langenbecks Arch Surg 385(8): 515-520.

9. Toursarkissian B, Sloan DA, Schwartz RW (1993) Coexisting hyperthyroidism and primary hyperparathyroidism. Surgery 113(6): 716-718.

10. Arem R, Lim-Abrahan MA, Mallette LE (1986) Concomitant Graves' disease and primary hyperparathyroidism. Influence of hyperthyroidism on serum calcium and parathyroid hormone. Am J Med 80(4): 693-698.
11. Xiao H, Yu B, Wang S, Chen G (2002) Concomitant Graves' disease and primary hyperparathyroidism: the first case report in mainland of China and literature review. Chin Med J (Engl) 115(6): 939-941.

12. Gannage MH, Abikaram G, Nasr F, Awada H (1998) Osteomalacia secondary to celiac disease, primary hyperparathyroidism, and Graves' disease. Am J Med Sci 315(2): 136-139.

13. Mosekilde L, Eriksen EF, Charles P (1990) Effects of thyroid hormones on bone and mineral metabolism. Endocrinol Metab Clin North Am 19(1): 35-63.

14. Abboud B, Sleilaty G, Mansour E, El Ghoul R, Tohme C, et al. (2006) Prevalence and risk factors for primary hyperparathyroidism in hyperthyroid patients. Head Neck 28(5): 420-426.

15. Wagner B, Begic-KS, Raber W, Schneider B, Waldhäusl W, et al. (1999) Prevalence of primary hyperparathyroidism in 13387 patients with thyroid diseases, newly diagnosed by screening of serum calcium. Exp Clin Endocrinol Diabetes 107(7): 457-461.

\section{Your next submission with Juniper Publishers} will reach you the below assets

- Quality Editorial service

- Swift Peer Review

- Reprints availability

- E-prints Service

- Manuscript Podcast for convenient understanding

- Global attainment for your research

- Manuscript accessibility in different formats ( Pdf, E-pub, Full Text, Audio)

- Unceasing customer service

Track the below URL for one-step submission https://juniperpublishers.com/online-submission.php 